\title{
AN EVALUATION OF STEAM-TREATED ASPEN AS A SUBSTITUTE FOR CORN SILAGE IN THE RATIONS OF LACTATING COWS
}

\author{
L. J. FISHER \\ Research Station, Agriculture Canada, Agassiz, British Columbia VOM IAO.
}

FisHer, L. J. 1980. An evaluation of steam-treated aspen as a substitute for corn silage in the rations of lactating cows. Can. J. Anim. Sci. 60: 379-384.

Fifteen lactating Holsteins were used to test processed aspen added to corn silage at the levels of 0,10 and $20 \%$ (dry matter basis). The experiment was designed as a latin square with three experimental periods each 42 days in length. The forage mixtures were fed free choice to the cows, which were housed in a free-stall barn, and their individual feed intakes were recorded by using electronic doors. The processed aspen contained $45.4 \%$ dry matter, $73.7 \%$ acid detergent fiber and $0.54 \%$ protein. There was no evidence of heating or mold growth in the aspen during the 5 mo of the trial. Silage dry matter intake and milk yield were 11.8,13.4 and 13.4 and 25.7, 27.0 and $26.8 \mathrm{~kg}$ per day, respectively, for the silage mixtures containing 0,10 and $20 \%$ processed aspen. Fat test was decreased slightly and milk protein content significantly $(P<0.05)$ depressed by the addition of $20 \%$ processed aspen chips to the corn silage. Efficiency of milk yield was not significantly influenced $(P>0.05)$ by the inclusion of aspen chips in the silage. Neither the molar proportion of acetic acid nor the ratio of acetic acid to propionic acid in the rumen fluid was changed when the cows were fed silage containing processed aspen chips. The apparent digestibilities of total ration dry matter and protein were lowered significantly by the addition of $10 \%$ aspen chips to the forage mixture. It was concluded from the results of this trial that steam-processed aspen chips had little nutritive value when fed to lactating cows as a partial substitute for corn silage.

On a utilisé 15 vaches Holstein en lactation pour évaluer les effets de l'addition de peuplir faux-tremble traité à la vapeur sur de l'ensilage de mais, à raison de 0,10 et $20 \%$ du mélange (base de matière sèche). Il s'agit d'un dispositif en carré latin comportant trois périodes expérimentales d'une durée de 42 jours chacune. On a servi les mélanges fourragers à volonté aux animaux en stabulation libre et enregistré leur ingestion individuelle d'aliments à l'aide de portes électroniques. Le peuplier faux-tremble contient $45.4 \%$ de matière sèche $73.7 \%$ de cellulose déterminée par détergent acide et $0.54 \%$ de proteines. Le peuplier n'a manifesté aucun échauffement ni croissance de moisissures au cours des 5 mois d'essais. L'ingestion de matière sèche de l'ensilage et la production laitière ont été de $11.8,13.4,13.4$ et de 25.7 , $27.0,26.8 \mathrm{~kg} / \mathrm{jour}$ respectivement pour les mélanges contenant 0,10 et $20 \%$ de peuplier traité. L'addition de $20 \%$ de copeaux traités à l'ensilage de maïs a légèrement et significativement $(P<0.05)$ réduit les teneurs en matière grasse et en protéines du lait respectivement. Cette addition n'a pas influé significativement sur la production laitière $(P<0.05)$. Le fait de servir aux vaches de l'ensilage contenant des copeaux traités n'a pas modifié la concentration molaire de l'acide acétique ni le rapport de la teneur en acide acétique à celle de l'acide propionique du liquide ruminal, mais l'addition de $10 \%$ de copeaux au mélange a significativement réduit les digestibilités apparentes de la matière sèche et des protéines totales de la ration. L'auteur conclut, d'après les résultats de cet essai, que les copeaux de peuplier traités à la vapeur ont peu de valeur nutritive comme succédanés partiels de l'ensilage de maïs servi aux vaches en lactation.

Can. J. Anim. Sci. 60: 379-384 (June 1980), 
The utilization of wastes from the forest industry or the processing of noncommercial trees into forms that can be consumed by ruminants has received considerable attention as outlined by Kitts and Krishnamurti (1976). The potential value of the cellulose in wood fiber as a dietary source of energy for livestock ranges from low for residues from the sulphite paper process (Murdock and Kromann 1977) and for fiber from softwoods (Heaney and Bender 1970) to an acceptable level for young hardwoods (Chaplin 1976). Satter et al. (1970) observed that when aspen sawdust was included in rations containing a high level of concentrate fed to lactating cows there was a marked increase in the fat content of milk. Increasing the digestibility of wood fiber by steam treatment has been observed by Bender et al. (1970) to improve animal performance more effectively than employing delignification with strong alkali (Wilson and Pigden 1964). It was the objective of this experiment to determine if steam-treated aspen (Populus tremuloides) (as produced by Stake Technology Ltd., 20 Enterprise Ave., Ottawa, Ont. K2A 0A6) was effective in acting as a partial substitute for corn silage in dairy cattle rations. The effectiveness of this substitution was measured by milk yield, milk fat percentage and changes in molar proportions of rumen volatile fatty acids.

\section{MATERIALS AND METHODS}

Fifteen Holstein cows in early lactation were subdivided into three groups that were balanced for age, body weight and potential milk yield. The experiment was designed as a latin square, wherein each treatment period consisted of 42 days and was separated from the next period by a 7-day changeover period. Treatment I consisted of corn silage fed free choice. Treatment II consisted of a forage mixture of $85.4 \%$ corn silage, $1.2 \%$ soybean meal and $13.4 \%$ aspen chips calculated on an as-fed basis. In treatment III, the forage mixture included $74.2 \%$ corn silage, $2.3 \%$ soybean meal and $23.6 \%$ aspen chips calculated on an as-fed basis. The forage mixtures fed in treatments II and III were mixed daily by hand. A concentrate mixture (Table 1) was fed in the milking parlor at the level of $1 \mathrm{~kg} / 4$ $\mathrm{kg}$ of milk yield. Cows were housed in a free-stall barn and were assigned to individual feed boxes controlled by electronic doors. The appropriate forage mixture was provided free choice (approx. $10 \%$ weightback) and the cows had access to water, salt and a mineral mixture.

Cows were weighed on 3 consecutive days at the beginning and end of each experimental period. Milk yield and feed intake were measured daily. Milk samples were obtained from four consecutive milkings per cow during the 3 rd and 6 th week of each experimental period and analyzed for fat, protein and lactose by IRMA (Courtesy of B.C.M.A. Laboratory, Burnaby, B.C., employing an infra-red milk analyzer). A sample of rumen fluid was taken between 0800 and $0900 \mathrm{~h}$ from each cow during the $3 \mathrm{rd}$ wk and again during the 6 th $w \mathrm{k}$ of each experimental period, The $\mathrm{pH}$ of rumen samples was determined immediately and the volatile fatty acid content of rumen fluid was determined by gas chromatography (Erwin et al. 1961).

Two cows from each treatment group were assigned to a 7-day total collection of urine and feces during the 5 th wk of each experimental period, in order to estimate the apparent digestibility of the dry matter (DM), protein and acid detergent fiber in the total ration. Feces from each cow were weighed daily and samples were analyzed for dry matter by oven-drying at $60^{\circ} \mathrm{C}$ for $48 \mathrm{~h}$. The seven samples from each cow collection period were composited and analyzed for nitrogen, acid detergent fiber (ADF), lignin, neutral detergent fiber (NDF) and ash (Goering and Van Soest 1970). Urine was analyzed for nitrogen content using an auto-analyzer.

A daily $500-\mathrm{g}$ sample of each forage mixture was obtained and refrigerated until the samples were pooled for each mixture, weekly, resulting in a total of 18 "as-fed" samples for each of the three experimental periods. A 500-g sample of grain was taken every 2 wk during each experimental period. A $200-\mathrm{g}$ sample of each cow's weighback was obtained once a week and pooled for chemical analysis for each cowtreatment period. A total of 45 weighback samples were obtained. Samples of the processed aspen chips were obtained weekly throughout the experiment. The samples of the silage mixture, weighback, grain and processed aspen chips oven-dried at $60^{\circ} \mathrm{C}$ to obtain DM and analyzed for nitrogen (auto-analyzer); ADF, lignin and ash 
Table 1. Dry matter content and chemical composition of ration components

\begin{tabular}{|c|c|c|c|c|c|c|c|}
\hline & \multirow{2}{*}{$\begin{array}{l}\text { No. of } \\
\text { obs. }\end{array}$} & \multirow{2}{*}{$\begin{array}{c}\text { Dry } \\
\text { matter } \\
(\%)\end{array}$} & Protein & $\mathrm{ADF}$ & NDF & Lignin & Ash \\
\hline & & & \multicolumn{5}{|c|}{$\%$ of dry matter } \\
\hline \multicolumn{8}{|l|}{ Forage mixtures } \\
\hline Corn silage & 18 & 28.2 & 7.90 & 24.93 & 30.4 & 5.89 & 3.71 \\
\hline Corn silage & & & & & & & \\
\hline $\begin{array}{l}+10 \% \text { aspen } \\
\text { Corn silage }\end{array}$ & 18 & 32.5 & 7.15 & 31.80 & 36.4 & 6.77 & 3.39 \\
\hline $\begin{array}{l}\text { Corn silage } \\
+20 \% \text { aspen }\end{array}$ & 18 & 34.7 & 6.98 & 35.69 & 43.8 & 6.85 & 3.11 \\
\hline Grain mixture & 9 & 90.0 & 23.43 & 7.89 & - & 2.05 & 3.71 \\
\hline $\begin{array}{l}\text { Processed aspen } \\
\text { chips }\end{array}$ & 18 & 45.4 & 0.54 & 73.7 & - & 14.98 & 1.38 \\
\hline
\end{tabular}

(Goering and Van Soest 1970), and silage samples were also analyzed for NDF.

Data were analyzed by analysis of variance and differences between the means for the control, and supplemented groups were tested by Duncan's multiple range test.

\section{RESULTS}

The average body weight, milk yield and total DM intake as a percent of body weight were $640 \mathrm{~kg}, 26.5 \mathrm{~kg} /$ day and $2.96 \%$ for the 15 lactating cows used in this trial.

The processed aspen contained $0.5 \%$ crude protein; hence, the forage mixtures II and III were formulated to be isonitrogenous by adding soybean meal (Table 1). Since all forage mixtures contained less than $8 \%$ protein, the grain mixture was formulated to contain $22 \%$ crude protein to provide a calculated level of $15 \%$ protein in the total ration (Table 1). Insufficient soybean meal was added to make the forages isonitrogenous as evidenced by differences in protein content of the three forage mixtures (Table 1). The acid detergent fiber (ADF) and lignin contents of the processed aspen chips were approximately twice that observed for an average quality forage whereas the ash content was considerably lower. The neutral detergent fiber content of the silage mixtures increased as the proportion of processed aspen chips in the forage mixture increased.

When expressed as either a percentage of body weight or total silage DM intake, the DM intake of the forage mixture was greater
$(P<0.05)$ for the corn silage plus aspen chip treatments than when corn silage was fed alone (Table 2). Milk yield per kilogram DM intake and body weight change were not affected by including processed aspen chips in the forage mixture (Table 2). There was no apparent difference in palatability of the forage mixtures with intake during the 1 st wk for each treatment, being 82,83 and $82 \%$ of maximum intake of that experimental period for 0,10 and $20 \%$ processed aspen chips in the forage mixture.

Actual milk yield was significantly greater $(P<0.05)$ for cows fed the processed aspen chips than for those fed only corn silage; however, this difference was not apparent when the milk yield was calculated as $4 \%$ fat-corrected milk (FCM) (Table 3). Milk fat and lactose contents were not influenced by the proportion of aspen in the silage mixture but the percentage of milk protein was significantly less $(P>0.05)$ when cows were fed $20 \%$ processed aspen in the forage mixture compared to corn silage fed alone. Efficiency of milk production expressed as kilograms of $4 \%$ FCM per kilogram of digestible DM intake was not significantly affected by the amount of aspen chips in the forage mixture (Table 3 ).

The addition of processed aspen chips to corns silage at either the 10 or $20 \%$ level did not change the $\mathrm{pH}$ of the rumen fluid compared to rumen fluid from cows fed only corn silage. Neither the molar proportion of 
Table 2. Influence of the proportion of processed aspen in the forage mixtures on body weight change, dry matter intake and efficiency of dry matter utilization

\begin{tabular}{|c|c|c|c|c|c|}
\hline & \multirow[b]{2}{*}{$\begin{array}{l}\text { Body wt (BW) gain } \\
\quad(\mathrm{kg} / 42 \text { days })\end{array}$} & \multicolumn{2}{|c|}{ Forage DMI $\dagger$} & \multirow{2}{*}{$\begin{array}{c}\text { Grain } \\
\text { DMI } \\
\mathrm{kg} / \text { day }\end{array}$} & \multirow{2}{*}{$\begin{array}{c}\text { Milk } \\
\text { yield kg } \\
\div \mathrm{DMI}^{\dagger} \\
\end{array}$} \\
\hline & & $\begin{array}{l}\% \text { of } \\
\text { BW }\end{array}$ & $\mathrm{kg} /$ day & & \\
\hline $\begin{array}{l}\text { Corn silage } \\
\text { Corn silage }\end{array}$ & 20.2 & $1.91 a$ & $11.84 a$ & 6.1 & 2.00 \\
\hline $\begin{array}{l}+10 \% \text { aspen } \\
\text { Corn silage }\end{array}$ & 15.4 & $2.17 b$ & $13.39 b$ & 6.3 & 2.03 \\
\hline $\begin{array}{l}+20 \% \text { aspen } \\
\text { SE of mean }\end{array}$ & $\begin{array}{r}20.8 \\
\pm 4.45\end{array}$ & $\begin{aligned} & 2.14 b \\
\pm & 0.078\end{aligned}$ & $\begin{array}{l}13.37 b \\
\pm 0.28\end{array}$ & 6.3 & $\begin{array}{r}2.04 \\
\pm 0.04\end{array}$ \\
\hline
\end{tabular}

$a, b$ Means with common letters in a column are not significantly different $(P>0.05)$.

†ry matter intake.

acetic acid in the rumen volatile fatty acids nor the ratio of acetate to propionate was affected by the addition of the aspen chips to the corn silage (Table 4). The apparent digestibility of ration DM and protein were significantly depressed $(P<0.05)$ by the addition of $10 \%$ aspen chips and depressed still further by the addition of $20 \%$ aspen chips (Table 5). There was no change in the digestibility of acid detergent fiber, which was relatively low for all three forage mixtures. The reduction in DM digestibility associated with the forage mixtures containing aspen chips may have partly been due to the higher intake $(P<0.05)$ observed for these rations compared to corn silage fed alone.

When a digestible DM content of $75 \%$ was assumed for the grain mixture, then the digestible dry matter (DDM) of the corn silage alone was significantly greater $(P<$ 0.05 ) than when $10 \%$ aspen chips were added to the corn silage. There was, however, no further reduction in silage DM digestibility when aspen chips were added at $20 \%$ of the silage mixture (Table 5). The addition of $10 \%$ aspen chips to the corn silage reduced DDM by $8.7 \%$, while the addition of $20 \%$ aspen chips reduced the silage mixture DDM by $10.8 \%$. Average digestible DM content of the corn silage fed in this trial was $66.4 \%$. Ash content of the feces was $10.0,9.0$ and $8.6 \%$ for cows fed the 0,10 and $20 \%$ aspen chips, respectively, reflecting the lower ash content of the processed aspen. Feces from the cows fed aspen were slightly drier than those fed only corn silage, being $14.5 \%, 15.1 \%$ and $15.2 \%$

Table 3. Influence of the proportion of processed aspen chips in the forage mixture on yield and composition of milk

\begin{tabular}{|c|c|c|c|c|c|c|}
\hline & \multicolumn{3}{|c|}{ Milk yield (kg/day) } & \multirow{2}{*}{\multicolumn{3}{|c|}{ Milk composition $(\%)$}} \\
\hline & \multirow[b]{2}{*}{ Total } & \multirow[b]{2}{*}{$4 \% \mathrm{FCM}$} & \multirow{2}{*}{$\begin{array}{l}4 \% \text { FCM } \dagger \\
\pm \text { D DMI }\end{array}$} & & & \\
\hline & & & & Fat & Protein & Lactose \\
\hline Corn silage & $25.73 a$ & 24.43 & 1.91 & 3.53 & $3.06 a$ & 4.96 \\
\hline Com silage & & & & & & \\
\hline$+10 \%$ aspen & $26.98 b$ & 24.19 & 1.82 & 3.37 & $3.01 a b$ & 5.00 \\
\hline Corn silage & & & & & & \\
\hline$+20 \%$ aspen & $26.80 b$ & 24.56 & 1.99 & 3.43 & $2.99 b$ & 4.99 \\
\hline$S E$ of mean & \pm 0.32 & \pm 0.49 & \pm 0.114 & \pm 008 & \pm 0.03 & \pm 0.02 \\
\hline
\end{tabular}

$a, b$ Means with common letters in a column are not significantly different $(P<0.05)$.

†Digestible dry matter intake.

+ Fat-corrected milk yield $(\mathrm{FCM} \mathrm{kg}=$ milk $\mathrm{kg}(.4+.15 \times \% \mathrm{~F})$ ).

$a, b$ Means with common letters in a column are not significantly different $(P<0.05)$. 
Table 4. Effect of proportion of aspen chips in the forage mixture on the molar proportions of rumen volatile fatty acids (VFA)

\begin{tabular}{lcccc}
\hline \hline & \multicolumn{4}{c}{ Mole \% VFA } \\
\cline { 2 - 5 } & Acetic & Propionic & Butyric & Acetic/propionate \\
\hline Corn silage & 52.0 & 27.4 & 16.6 & 2.09 \\
$\quad$ Corn silage & & & & \\
$\quad+10 \%$ aspen chips & 50.6 & 27.7 & 17.1 & 1.93 \\
Corn silage & & & & \\
$\quad \quad$ 20\% aspen chips & 51.1 & 26.7 & 17.0 & 1.94 \\
SE of mean & \pm 1.41 & \pm 1.79 & \pm 0.98 & \pm 0.19 \\
\hline
\end{tabular}

Table 5. Effect of proportion of aspen chips in the forage mixture on apparent digestibility of dry matter, protein and acid detergent fiber (ADF)

\begin{tabular}{|c|c|c|c|c|c|c|}
\hline & \multirow[b]{2}{*}{$\begin{array}{c}\mathrm{DMI}^{\dagger} \\
\text { (kg/day) }\end{array}$} & \multicolumn{5}{|c|}{ \% Apparent digestibility } \\
\hline & & $\begin{array}{c}\mathrm{N} \ddagger \\
(\mathrm{g} / \text { day })\end{array}$ & $\begin{array}{c}\text { Total } \\
\text { ration } \\
\text { dry matter }\end{array}$ & Protein & $\mathrm{ADF}$ & $\begin{array}{c}\text { Silage } \\
\text { dry } \\
\text { matter\$ }\end{array}$ \\
\hline $\begin{array}{l}\text { Corn silage } \\
\text { Corn silage }\end{array}$ & $17.95 a$ & +7.2 & $69.3 a$ & $67.5 a$ & 33.9 & $66.4 a$ \\
\hline $\begin{array}{l}+10 \% \text { aspen chips } \\
\text { Corn silage }\end{array}$ & $19.32 b$ & +4.0 & $65.6 b$ & $65.0 a b$ & 33.6 & $60.6 b$ \\
\hline $\begin{array}{l}+20 \% \text { aspen chips } \\
\text { SE of mean }\end{array}$ & $\begin{array}{l}19.55 b \\
\pm 0.422\end{array}$ & $\begin{array}{r}-4.5 \\
\pm 8.66\end{array}$ & $\begin{array}{l}63.6 c \\
\pm 0.38\end{array}$ & $\begin{aligned} & 63.5 b \\
\pm & 1.04\end{aligned}$ & $\begin{array}{c}33.1 \\
\pm 2.91\end{array}$ & $\begin{array}{l}59.2 b \\
\pm 0.85\end{array}$ \\
\hline
\end{tabular}

$\dagger$ Dry matter intake during the digestion trial.

$\uparrow$ Nitrogen retention.

$\$$ Calculated from an assumed digestibility of $75 \%$ for grain mix.

$a, b$ Means with common letters in a column are not significantly different $(P>0.05)$.

dry matter for 0,10 and $20 \%$ aspen chips, respectively.

\section{DISCUSSION}

This study was carried out with a steam-treated aspen chip product, not unlike peat moss in its appearance, which had been processed according to the system used in the manufacture of the commercial product "Pro-Cell"' (Stake Technology Ltd., 20 Enterprise Ave., Ottawa, Ontario K2A 0A6). Previous experiments (Satter et al. 1970,1973 ) indicated that aspen sawdust was an effective roughage replacement in high concentrate rations when it was included at 10,20 or $30 \%$ of the concentrate mixture fed to lactating cows. At those levels, unprocessed aspen sawdust increased milk fat percentage, rumination time and the acetate to propionate ratio without depressing milk yield appreciably. However, in our study, the inclusion of steam-treated aspen at similar levels, calculated on the basis of total DM intake, did not affect either milk fat percentage or the molar proportions of the rumen volatile fatty acids. Sharma et al. (1979) observed an increase in the proportion of rumen acetate and a decrease in that of propionate when steam-processed aspen was included at $45 \%$ of the total DM in the ration fed to sheep; but there was no significant influence on the molar proportion of rumen volatile fatty acids when steamprocessed aspen was included at levels of 15 and $30 \%$ in the total diet. It would appear from the observations on changes in the molar proportions of rumen fluid (Sharma et al. 1979; Forsberg et al. 1977) and the results 
of our trial that either the steam processing reduced the effective fiber content of the aspen or that it has to be included at greater than $30 \%$ of the total ration in order to have an influence on rumen volatile fatty acids or percentage of milk fat.

Al Rabbat and Heaney (1978), using sheep, found that the feeding of a high level of steam-treated aspen resulted in rumen fermentations characteristic of high fiber rations. The observation common to many studies has been the depression in the dry matter digestibility of the total ration. The stimulation of appetite (Sharma et al. 1979) was also observed in our study with lactating cows but was, in this instance, attributed to the lower digestibility of the total ration and the ability of lactating cows producing in excess of $25 \mathrm{~kg}$ of milk per day to increase forage intake to compensate for a dilution of energy in the ration. This conclusion is supported by the observation of Satter et al. (1970), that cows fed unprocessed aspen sawdust increased their dry matter intake to compensate for the lower digestibility of the ration.

The results of this study, where processed aspen was fed at 10 and $20 \%$ of the forage dry matter to lactating cows, indicated that it was not effective in altering rumen fermentation and increasing milk fat percentage. Under the conditions of this study, steamprocessed aspen chips had little economic value in the formulation of rations for lactating cows.

\section{ACKNOWLEDGMENTS}

The author wishes to express his appreciation to A. Krahn and J. Wolff and their staff for the feeding, milking and care of the animals during this study and to D. Helkenberg and Sharon Jones for the chemical analysis and computation of the data.

AL-RABBAT, M. F. and HEANEY, D. P. 1978. The effects of anhydrous ammonia treatment of wheat straw and steam cooking of aspen chips on their feeding value and on rumen microbial activity. I. Feeding value assessments using sheep. Can. J. Anim. Sci. 58: 443-451.
BENDER, F., HEANEY, D. P. and BOWDEN, A. 1970. Potential of steam wood as a feed for ruminants. For. Prod. J. 20: 36-41.

CHAPLIN, R. K. 1976. Evaluation of processed aspen as livestock feed. Pages 1-7 in Wood Wates as Livestock Feed Symp. Proc., Animal Science Lead Committee and British Columbia Ministry of Agriculture.

ERWIN, E. S., MARCO, G. J. and EMERGY, E. M. 1961. Volatile fatty acid analysis of blood and rumen fluid by gas chromatography. J. Dairy Sci. 44: $1768-1771$.

FORSBERG, N. E., GUENTER, W. and INGALLS, J. R. 1977. Utilization of steamed whole aspen by ruminants. Can. J. Anim. Sci. 57: 844-845 (Abstr.).

GOERING, H. K. and VAN SOEST, P. J. 1970.

Forage fiber analyses (apparatus, reagents, procedures and some applications). U.S. Dep. Agric. Handb. No. 379. Pp. 8-9.

HEANEY, D. P. and BENDER, F. 1970. The feeding value of steamed aspen for sheep. For.

Prod. J. 20: 98-102.

KITTS, W. D. and KRISHNAMURTI, C. R. 1976. Utilization of wood wastes in feeding livestock. Pages 1-22 in Wood Wastes as Livestock Feed. Symp. Proc., Animal Science Lead Committee and British Columbia Ministry of Agriculture.

MURDOCK, F. R. and KROMANN, R. P. 1977. The digestibility and nutritive value for dairy heifers of rations containing cellulose fibre. Anim. Feed Sci. Tech. 2: 287-295.

SATTER, L. D., BAKER, A. J. and MILLETT, M. A. 1970. Aspen sawdust as a partial roughage substitute in a high-concentrate dairy ration. J. Dairy Sci. 53: 1455-1460.

SATTER, L. D., LANG, R. L., BAKER, A. J. and MILLET, M. A. 1973. Value of aspen sawdust as a roughage replacement in high concentrate dairy rations. J. Dairy Sci. 56: 1291-1297.

SHARMA, H. R., FORSBERG, N. E. and GUENTER, W. 1979. The nutritive value of pressure steamed aspen (Populus tremuloides) for mature sheep. Can. J. Anim. Sci. 59: 303-312.

WILSON, R. K. and PIGDEN, W. J. 1964. Effect of a sodium hydroxide treatment on the utilization of wheat straw and poplar wood by rumen microorganisms. Can. J. Anim. Sci. 44: $122-123$. 